\title{
The Effect of Resilience and Cognition on (Im)Migrant Students' Academic Adaptation
}

\author{
Emily Souza Gaião e Albuquerque ${ }^{1}$ \\ José Maurício Haas Bueno' \\ ${ }^{1}$ Universidade Federal de Pernambuco
}

\begin{abstract}
This study aimed to identify cognitive (reasoning and executive functions) and resilient behavioral variables of (im)migrant university students which are related to different aspects on their adaptation to academic experiences. It is a descriptive exploratory cross-sectional study. The sample consisted of 64 undergraduate and graduate students from three universities of Porto Alegre, with average age 23.75 years old (DP $=2.9)$, from other Brazilian state or other country. The results pointed that significant predictors of all five academic experiences' dimensions were resilience's aspects and none cognitive. Among these resilience's aspects, it was highlighted Structured style, which predicted three different dimensions. Those findings show the relevant role of resilience in adaptive process faced by this population and, consequently, in their academic success.

Keywords: adaptation, resilience (psychology); cognitive processes; university students
\end{abstract}

\section{O Efeito da Resiliência e Cognição na Adaptação Acadêmica de Estudantes (I)Migrantes}

\begin{abstract}
Resumo
O presente estudo teve como objetivo identificar variáveis cognitivas (raciocínio e funções executivas) e de comportamentos resilientes de estudantes universitários (i)migrantes que estivessem associadas aos diferentes aspectos envolvidos na sua adaptação à vida acadêmica. Trata-se de um estudo descritivo de caráter transversal. A amostra foi composta por 64 estudantes universitários de graduação e pós-graduação de três universidades de Porto Alegre, com média de idade de 23,75 anos ( $D P=$ 2,9), naturais de outros estados brasileiros ou de outra nacionalidade. Os resultados indicaram que os preditores significativos das cinco dimensões das vivências acadêmicas foram aspectos da resiliência, não tendo sido encontrado nenhum preditor significativo de ordem cognitiva. Entre esses aspectos da resiliência, o "estilo estruturado" se destacou, por ter sido o preditor de três critérios distintos. Tais achados apontam para o relevante papel da resiliência no processo adaptativo enfrentado por essa população e, consequentemente, no sucesso acadêmico deles.

Palavras-chave: adaptação, resiliência (psicologia), processos cognitivos, universitários
\end{abstract}

Efecto de la Resiliencia y Cognición en la Adaptación Académica de Estudiantes (In) Migrantes

\section{Resumen}

El presente estudio tuvo como objetivo identificar las variables cognitivas (razonamiento y funciones ejecutivas) y comportamientos de resiliencia de estudiantes universitarios (in)migrantes que estuvieran asociados a los diferentes aspectos implicados en su adaptación a la vida académica, tales como: personal, interpersonal, estudio, carrera e institucional. Se trata de un estudio descriptivo de carácter transversal. La muestra fue compuesta por 64 estudiantes universitarios graduados y posgraduados de tres universidades de Porto Alegre, con promedio de edad de 23,75 años (DP $=2,9$ ), oriundos de otros estados brasileños o de otra nacionalidad. Los resultados indicaron que los predictores significativos de las cinco dimensiones de experiencias académicas fueron aspectos de la resiliencia, no siendo encontrado ningún predictor significativo de orden cognitivo. Entre esos aspectos de la resiliencia, el "estilo estructurado" se destacó por haber sido el predictor de tres criterios distintos. Tales resultados apuntan para el relevante papel de la resiliencia en el proceso adaptativo enfrentado por esta población y, como consecuencia, en su éxito académico.

Palabras clave: adaptación; resiliencia (psicología); procesos cognitivos; universitarios

Global migration has been a significant process in recent years. Among the migrants are international students, who crossed a national or territorial boundary for educational purposes and are currently enrolled outside their country of origin (UNESCO, 2014). The undergraduate students, from the 20 countries with the largest number of foreign students, enrolled in Brazil in 2017 were approximately 13,000 (Ministry of Education, 2018). In addition, there is a large number of students who change region/state with the same goal. In 2017, about 21 thousand Brazilians changed their state to enter higher education (Bermúdez, 2018).

These students face a wide variety of adversities, such as the search for housing, concern for safety, and problems with living with their peers (Terry, Yue, \& Lê, 2014). In addition, language issues, differences between education systems and missing their family are reported as difficulties faced by them (Perlin, Vestena, Damke, 
Patias, \& Gomes, 2018). These factors may lead students to develop some mental disorder such as anxiety and depression (Araújo et al., 2016), making the adaptive process more difficult.

In addition to these issues, the students are also required to adapt to the new university context, which is a multifaceted process that involves coping with academic demands, social relationships, aspects related to personal identity and vocation (Polydoro, Primi, Serpa, Zaroni, \& Pombal, 2001). The academic adaptation involves numerous personal, interpersonal and vocational aspects, as well as those related to the students' study habits and their feelings towards the institution (Santos, Noronha, Amaro, \& Villar, 2005; Carvalho, Teodoro, \& Borges, 2014), thus resulting in the interaction between cognitive, social and affective processes (Soares \& Del Prette, 2015) and being unique for each person, considering different mediating factors of the stress-adaptation relationship.

In other words, in response to such risk events, the person may show resilient or vulnerable behaviors (Luthar, 2015). In addition to resilience, other factors have been identified as important for adaptation situations, such as executive functions (EFs) (Masten et al., 2012; Ribeiro, Calado, \& Oliveira, 2016) and fluid intelligence (Soares, Seabra, \& Gomes, 2014).

In resilience, protective factors relate to life events and mobilize psychological processes that promote emotional health and adaptation. It is composed of three broad categories: 1) familial support, involving parenting, interpersonal dynamics, cohesion, rituals and norms; 2) external family support systems, such as peers, school, cultural and social systems; and 3) individual positive disposition attributes, which include aspects of personality, brain learning systems, motivational control systems, stress response and self-regulation (Masten \& Obradović, 2006). Thus, resilience must be understood as a complex phenomenon composed of cognitive and psychosocial aspects.

The first two categories concern the social dimension, internal and external to the family. In this aspect, university students with more developed social skills tend to show less feelings of loneliness (Ozben, 2013) and being less vulnerable to developing depression or anxiety (Bolsoni-Silva \& Loureiro, 2015). Such abilities are also positively and significantly correlated to secure attachment in this population (DiTommasoa, Brannen-McNulty, Rossb, \& Burgessa, 2003), which is characterized by trust, generosity and tolerance in the relationship to themselves and to authors, as well as emotional autonomy (Kobak, 1993).
In addition, the performance in academic activities also seems to influence the establishment of interpersonal relationships, since students tend to take this into consideration when selecting friends (Gremmen, Dijkstra, Steglich, \& Veenstra, 2017). These results suggest that good social skills and good performance in academic activities contribute to the establishment of relationships based on secure attachment, building stronger relationships that can function as protective factors in the adaptive process.

Still on the subject of the social dimension, the institution also plays an important part in the adaptation of the students, functioning as a support system external to the family, which favors the resilient behavior. This is because institutional support is associated with motivation for academic tasks, which in turn translates into a set of engaging learning behaviors (Dupont, Galand, \& Nils, 2015).

On the third category, the individual positive disposition attributes, studies show that self-efficacy is an important factor for the health and welfare of students (Townsend \& Scanlan, 2011). Thus, it is possible that the confidence in their own abilities contributes to this population having positive experiences in the academic context.

In addition to resilience, EFs are among the factors that contribute to adaptation in situations of vulnerability. Those are the higher order cognitive processes, contributing to the process of adapting to unknown or complex situations (Chan, Shum, Toulopoulou, \& Chen, 2008) and are built of three central functions: 1) inhibition control, related to attention, behavior and/ or emotional control to perform a more adequate or necessary action, overcoming a strong internal predisposition; 2) working memory, which is the ability to keep one information in mind in order to work on it; and 3) cognitive flexibility, which involves, among other things, the changing of a thought on a subject, flexibility to adapt to the changes in demands and priorities (Diamond, 2013).

In situations where adaptation and flexibility of behavior are demanded, EFs are decisive and may predict the direction and regulation of various intellectual, emotional and social competences, enabling a healthy adaptive process (Ribeiro et al., 2016).In addition, studies show that the EFs are related to quality of life (Lopes, Bastos, \& Argimon, 2017; Vries \& Geurts, 2015) and resilience (Greenberg, 2006), being both an adaptation indicator in children facing vulnerability for lack of housing (Masten et al., 2012) and a mediator of 
risk factors and academic success (Blakemore \& Bunge, 2012). Thus, it is possible to think that interventions at the level of cognitive processing can promote a healthy adaptation in contexts of vulnerability.

In addition, EFs are also related to action planning (Diamond, 2013) and, in the case of (im)migrant students, such actions would be career-oriented. Theoretical discussions support the existence of a deeper articulation between career development and academic processes, from which one can deduce that a career can (and should) be discussed, planned and constructed throughout life, including the school and academic phases (Oliveira \& Taveira, 2016). There are several important impacts arising from career commitment among university students, such as good academic performance and low dropout rates (Bardagi \& Hutz, 2012).

Another cognitive process that could influence the adaptation of these students would be fluid intelligence, a skill related to the flexible and deliberate control of attention in order to identify rules and patterns (inductive reasoning) and thus solve problems (Schneider \& Newman, 2015). High scores of fluid intelligence seem to be related to the ability to interact with the activities and social relations of the new university daily life (Soares et al., 2014), as well as with the academic achievement of students who are adapting to the university context (Primi, Santos, \& Vendramini, 2002).

In addition, studies point to a relationship between resilience and cognition aspects in the process of adapting to situations of vulnerability (Cheng \& Furnham, 2014; Grech et al., 2015, Wigtil \& Henriques, 2015, Zhou, Lin, \& Lin, 2015). In view of this evidence, the present study aimed to identify the cognitive variables (reasoning and executive functions) and of resilience that were associated with the different aspects involved in adapting to the academic life of (im)migrant students, who, because of this condition, are more likely to experience these adaptation processes and their respective situations of vulnerability. Thus, we expected to find cognitive and resilience aspects among the predictive variables of more positive academic experiences.

\section{Method}

\section{Participants}

The sample consisted of 64 undergraduate and graduate students from three universities in the city of Porto Alegre - RS, from other Brazilian states or from other countries. To select the participants, we followed a non-probabilistic strategy.

They were mostly women $(52.3 \%)$, foreigners (79.7\%), Latin Americans (50\%), undergraduate students $(75 \%)$ in humanities courses $(53.8 \%)$. The average age of participants was 23.75 years $(S D=$ 2.9), ranging from 20 to 33 years old. The average residence time in Porto Alegre was 6 months $(S D=12.2)$, ranging from 1.5 to 96 months. Regarding nationality, the sample had people from 15 countries, from Latin America, Europe, Asia and Africa. The most frequent countries (1) and languages (2) were: (1) Argentina $(21.9 \%)$ and Brazil (20.3\%) and (2) Spanish (52.3\%) and Portuguese (23.1\%).

It should be noted that the restricted number of participants resulted from the fact that this population is not so broad compared to the group of university students in general. In addition, the instruments selected for data collection required individual interviews, making it impossible to apply to groups.

\section{Instruments}

We used five instruments for the data collection: a sociodemographic questionnaire, the Abstract Reasoning test of the Battery of Reasoning Tests (BPR-5) (Primi \& Almeida, 2000); the Wisconsin Card Sorting Test - WCST (Heaton, Chelune, Talley, Kay, \& Curtiss, 2005; Silva-Filho, 2012); the Resilience Scale for Adults - RSA (Hjemdal, Roazzi, Dias, Roazzi, \& Friborg, 2009) and the Academic Experiences Questionnaire, short version (QVA-r) (Santos et al., 2005).

Although the participants were of different nationalities, the QVA-r and the RSA were used in their versions adapted and validated for the Brazilian cultural context. It should be noted that all participants were able to communicate reasonably in Portuguese, presenting only difficulties in understanding specific words, whose meanings were clarified by the applicator.

\section{Sociodemographic questionnaire}

This questionnaire collected biographical and socio-occupational data (age, sex, marital status, education, profession, nationality, family income range, residence time in Porto Alegre, exchange duration and objective, etc.). These questions aimed to characterize the sample and the participants' type of exchange.

\section{Resilience Scale for Adults (RSA)}

The RSA is a self-report tool developed to measure protective factors related to resilience. The 
Brazilian Portuguese version of RSA has 33 items that are answered on a seven-point scale in a semantic differential format. Each item is systematized in a continuum, where opposites express possibilities for responses with positive and negative content (example: "When something unexpected happens ... I usually feel bewildered ******* I always find a solution"). Between the negative extreme ("I usually feel bewildered") and the positive ("I always find a solution") there were seven squares for respondents to choose the one that best applied to themselves. Subsequently, these choices were assigned values from 1 (negative extreme) to 7 (positive extreme), so that low scores indicated little resilience in the factor evaluated, and high scores, high resilience. The items in this instrument cover six factors: 1) Perception of the Self $(\alpha=0,75)$, which evaluates the confidence the person has in their own abilities, self-confidence, self-efficacy, positive perspective, realistic expectations; 2) Planned Future $(\alpha=0,67)$, with items that measure the planning ability, optimistical envisioning of the future, goal orientation; 3) Social Competence $(\alpha=0,68)$, measures the extraversion level, social flexibility, ability to establish friendships, humor self-perception; 4) Structured Style $(\alpha=0,56)$, assessing goal orientation, planning, ability to organize their own time, oriented rules/routine; 5) Family Cohesion $(\alpha=0,79)$, assessing the values shared in the family, appreciation for being with the family, cohesion level, shared optimistic vision of the future, loyalty and mutual appreciation; and 6) Social resources $(\alpha=0,77)$, which measures the perception of social support, of important people outside the family circle, encouragement, cohesion feeling, access to help when needed and appreciation of others (Hjemdal et al., 2009).

\section{Academic experiences questionnaire (QVA-r)}

We used the reduced version of this instrument, which was adapted and validated for the Brazilian context. Comprised of 55 items, answered in a Likert scale and distributed into five factors regarding the areas of academic adaptation: (1) personal $(\alpha=0,84)$, on physical and psychological wellbeing, affective stability, emotional balance, emotional equilibrium, optimism and the students' self-confidence; (2) interpersonal $(\alpha=0,82)$, on the capacity of relating in a situation of intimacy, the relations with colleagues, establishing friendships and seeking help; (3) career $(\alpha=0,86)$, on feelings regarding the course, career perspective and the students' vocational projects; (4) study $(\alpha=0,78)$, describes habits on studying, time management, use of learning resources on campus and preparation for exams; and (5) institutional $(\alpha=0,77)$, gathering the students' assessment about the institution the attend, along with a will to stay or change institution, the knowledge and appreciation of its infrastructure (Santos et al., 2005).

\section{Wisconsin Card Sorting Test (WCST)}

The WCST (Heaton et al., 2005) assesses abilities strongly associated with executive functions, such as the ability to change cognitive strategies in response to changes in environmental contingencies. It consists of two equal decks with 64 cards each and four stimulus cards, which have attributes such as color, number and shape. Participants must rate the 128 cards according to one of the attributes of the stimulus cards, which they must discover themselves. For each classified card, they get a "'feedback.", which they should use as a reference for sorting the next card. The form of classifying the cards changes automatically after ten hits, but this change is not communicated to the participant, requiring cognitive flexibility and inductive reasoning to discover the new rule of card classification. This operation is the same for both the original test and its electronic version (E-WCST) (Silva-Filho, 2012), which was used in this study. The scoring is based on the frequency and the percentage of occurrence of each type of response in relation to the total of answers. In this study, only the percentage of perseveration errors was used. The WCST psychometric studies found reliability indices with experienced raters between 0.91 and 0.96 and with novice raters between 0.75 and 0.97 (Heaton et al., 2005).

\section{Abstract Reasoning Test (AR) of the Reasoning Test Battery (BPR-5)}

The Abstract Reasoning Test (AR) of BPR-5 ( $\alpha$ $=0.79)$, is a subtest that evaluates fluid intelligence. It consists of 25 items involving analogies with geometric figures (A: B / C: (A, B, C, D, E). In this test, it is necessary to find the relation between the first two figures ( $A$ and $B$ ) and use it to find out the relation between a figure $\mathrm{C}$ and one of the five answer alternatives (A, B, $\mathrm{C}, \mathrm{D}$ or $\mathrm{E})$. The maximum time for the test is $12 \mathrm{~min}$ utes and the total score of each participant corresponds to their number of right answers. Statistically significant correlations between the scores of this BPR- 5 subtest with school performance were found, ranging from 0.23 to 0.40 (Primi \& Almeida, 2000). 


\section{Procedures}

Data collection was done after approval of the project by a Research Ethics Committee (CAAE $\mathrm{n}^{\circ}$ 38249214.2.0000.5208). The students were invited to the face-to-face interview by the International Relations sector of the HEIs and by social networks. We also used the snowball strategy. Those who agreed to the Informed Consent Term participated in the study. The instruments were answered in a single meeting of approximately 40 minutes in which they first answered the QVA-r, followed by the RSA, the sociodemographic questionnaire, the WCST and the AR test of the BPR-5. The interviews were conducted in rooms of a public HEI in the city of Porto Alegre by a single duly trained applicator.

\section{Data analysis}

The data were stored in spreadsheet and analyzed with the help of the Statistical Package for Social Sciences (SPSS) version 20.0. Initially, the accuracy of RSA and QVA-r factors was investigated by means of Cronbach's Alpha. Next, we did descriptive statistics of measures of central tendency and dispersion to describe the performance of the participants in the instruments used in this study. Moreover, we developed multiple linear regression analyzes with input data by the stepwise method, to investigate whether cognitive factors (AR and E-WCST) and resilience (RSA) would be good predictors of academic experiences factors (QVA-r). It should be noted that a regression was performed for each QVA-r factor.

\section{Results}

In the Cronbach's alpha analyzes of QVA-r factors, scores ranging from 0.63 (institutional) to 0.87 (personal) were found. The RSA precisions, in turn, varied between 0.58 (social resources) and 0.81 (family cohesion). Descriptive statistics were used to show that the QVA-r participants ranged from 3.44 (SD = $0.5)$ (institutional) to 3.98 (SD $=0.49)$ (career) and RSA, between 4.85 (structured style) and 5.97 (social resources). For WCST, a perseverative error rate of 11.7 (SD $=7.95$ ) was found. Finally, the average accuracy in the abstract reasoning test of BPR-5 was 11.95 $(\mathrm{SD}=3.33)$.

To analyze which variables studied would be predictors of academic adaptation we $>$ held multiple linear regression analysis for each dimension of QVA-r (criteria) by inserting the factors of RSA, the perseverative Error percentage of WCST and scores of $\mathrm{AR}$ as predictors. Most of the variables involved presented a normal distribution, allowing the use of the proposed analysis. The regression coefficients for the five dimensions of the academic experiences are presented in Table 1.

It can be observed that for the personal dimension of academic experiences, the significant predictors were the self-perception and structured style factors. As for the interpersonal dimension, the significant predictors found were social competence and structured style. Only the planning factor of the future appeared as a significant predictor of the career dimension of academic experiences. Moreover, it was also observed that the structured style factor was the only significant predictor of the study dimension of academic experiences. Finally, the institutional dimension of academic experiences, met as a significant predictor the factor of resilience social resources.

It can be seen that five aspects of resilience are associated with adaptation to academic experience. The only factor of the RSA that did not appear among the predictors was family cohesion. Among these aspects of resilience, the structured style was the one that stood out, being the predictor of three distinct criteria (personal, interpersonal and study), which are perhaps the most important for a more immediate adaptation of migrant students. In addition, it is also verified that no significant predictor of cognitive order was found. Given that RSA items assess protective factors related to resilience (Hemal et al., 2009), this result indicates that the importance of attention to these factors is important for the success of the students' adaptive process.

\section{Discussion}

This study aimed to identify cognitive variables (reasoning and executive functions) and resilience that were associated to the different aspects involved in adapting to the academic life of (im)migrant students. The averages of the participants' scores on the QVA-r and the RSA indicate, in general lines, that the participants tended to present indicators of academic experiences and resilience ranging from intermediate to good. Regarding the cognitive variables, WCST results indicated that the performance of the sample was characteristically lower than that of the normative (American) sample (Heaton et al., 2005). However, the average of the participants' scores in the RA test 
Table 1.

Coefficients of QVA dimension predictors

\begin{tabular}{|c|c|c|c|c|c|}
\hline \multirow{2}{*}{$\begin{array}{l}\text { Model } \\
\text { B }\end{array}$} & \multicolumn{2}{|c|}{$\begin{array}{c}\text { Non-standardized } \\
\text { Coefficients }\end{array}$} & \multirow[t]{2}{*}{$\begin{array}{c}\text { Standardized } \\
\text { Coefiicients }\end{array}$} & \multirow{2}{*}{$\mathrm{T}$} & \multirow{2}{*}{ Sig. } \\
\hline & $\begin{array}{l}\text { Standard } \\
\text { Error }\end{array}$ & Beta & & & \\
\hline \multicolumn{6}{|l|}{ Personal } \\
\hline 1 (Constant) & 1.64 & 0.41 & & 3.95 & 0.00 \\
\hline Self-perception & 0.39 & 0.07 & 0.53 & 5.02 & 0.00 \\
\hline 2 (Constant) & 1.13 & 0.44 & & 2.57 & 0.01 \\
\hline Self-perception & 0.31 & 0.08 & 0.43 & 3.92 & 0.00 \\
\hline Structured Style & 0.18 & 0.07 & 0.28 & 2.61 & 0.01 \\
\hline \multicolumn{6}{|l|}{ Interpersonal } \\
\hline 1 (Constant) & 1.82 & 0.33 & & 5.47 & 0.00 \\
\hline Social Competency & 0.30 & 0.06 & 0.54 & 5.05 & 0.00 \\
\hline 2 (Constant) & 1.29 & 0.39 & & 3.25 & 0.00 \\
\hline Social Competency & 0.30 & 0.05 & 0.53 & 5.12 & 0.00 \\
\hline Structured Style & 0.11 & 0.05 & 0.53 & 2.30 & 0.02 \\
\hline \multicolumn{6}{|l|}{ Career } \\
\hline 1 (Constant) & 2.34 & 0.23 & & 10.0 & 0.00 \\
\hline Future planning & 0.31 & 0.04 & 0.67 & 7.15 & 0.00 \\
\hline \multicolumn{6}{|l|}{ Study } \\
\hline 1 (Constant) & 2.02 & 0.23 & & 8.47 & 0.00 \\
\hline Institutional Structured Planning & 0.34 & 0.04 & 0.67 & 7.23 & 0.00 \\
\hline \multicolumn{6}{|l|}{ Institutional } \\
\hline 1 (Constant) & 1.66 & 0.55 & & 2.98 & 0.00 \\
\hline Social Resources & 0.29 & 0.09 & 0.37 & 3.20 & 0.00 \\
\hline
\end{tabular}

was close to that of a sample with university students (Almeida et al., 2010). These results indicate that there are no major differences, more or less, in the participants' cognitive performance.

The results of the predictions indicated that the predictors of the five dimensions of academic experiences were aspects of resilience, and no predictor of cognitive order was found. These results contradict the evidence both of the relationship between resilience and aspects of cognition in adaptation processes to situations of vulnerability (Cheng \& Furnham, 2014; Grech et al, 2015; Greenberg, 2006; Wigtil \& Henriques, 2015; Zhou et al., 2015), and the role of EFs and fluid intelligence for a healthy adaptation (Ribeiro et al., 2016; Soares et al., 2014; Primi et al., 2002).

One of the possible explanations for this is that the instruments used to evaluate the academic experiences and the resilience were self-reported, while the EFs and the fluid intelligence were based on performance. This may have influenced the result found, since these two types of measures may not correlate, even when they operate in the same theoretical perspective, evaluating the same variable (Costa \& Faria, 2014).

It was also found that five of the six factors of resilience appeared as significant predictors of at least one aspect of adaptation to academic experiences. With emphasis on structured style for having predicted the personal, interpersonal and study dimensions, that assess aspects of planning and organization of time, rules and routine aiming at a goal (Hjemdal et al., 2009). These abilities demand attentional, behavioral and emotional control, suggesting a possible relationship between the structured style and the inhibitory control of EFs. This hypothesis, however, could not be 
verified since WCST would not be the most appropriate instrument for the evaluation of inhibitory control and should be explored in future studies.

By analyzing each dimension of the academic experience in more detail, we noticed that, for the personal factor, the predictors were the aspects related to the perception of self and the resilience's structured style. This result indicates that the (im)migrant students' adaptation as to their physical and emotional wellbeing, affective and emotional stability optimism and self-confidence(personal aspects of the academic experiences, according to Santos et al., 2005), may be predicted both for the sureness with which the students perceive their own abilities (perception of self, as defined by Carvalho et al., 2014) as for their ability of time management, goals, deadlines, rules and routines (structured style, by Carvalho et al., 2014). This result corroborates those obtained in Townsend and Scanlan's (2011) research, indicating that there is some consistency in the idea that trust in one's own abilities (self-efficacy and self-perception) and organization for academic tasks (structured style) favor the general well-being, including the good quality of personal academic experiences.

In turn, the interpersonal factor of academic experiences had as significant predictors the aspects of social competence and, again, structured style of resilience. Thus, the ability of relating in an intimacy situation, the relations with colleagues, establishing friendships and seeking help (interpersonal aspects of academic experiences, according to Santos et al., 2005) may be predicted both for the ability to start dialogues, establish and maintain new friendships and good social relations (social competence, as defined by Carvalho et al., 2014), as for the ability to manage time, goals, deadlines, rules and routines (structured style, Carvalho et al., 2014).

The relationship between the interpersonal factor and social competence appears to occur due to the convergence between the definitions of these constructs since both refer primarily to the ability to relate to others, comprising from abilities in initial interactions, such as initiating a dialogue, or the ability to engage in more intimate relationships. This result seems compatible with others found in the literature (Bolsoni-Silva \& Loureiro, 2015; Di Tommasoa et al., 2003; Ozben, 2013). Succinctly, the adaptation of these students can be facilitated by their ability to build, more or less quickly, a social support network that they can count on in situations of difficulty.
The interpersonal aspects of academic experiences were also significantly predicted by the structured style of resilience. Similar results have been found in the literature (Gremmen et al., 2017), indicating that it is likely that by the demand for group activities in the academic environment, for example, students who are perceived as more disciplined are more sought after by other students for the accomplishment of these activities, favoring the interpersonal adaptation in the academic environment.

The career dimension of academic experiences had as a predictor only the resilience's planning of the future. Therefore, the analysis of feelings about the course, career plans and projects of the students (definition of the career factor, according to Santos et al., 2005) can be explained by the positive view that students have regarding their future, and planning for well-defined and achievable goals, as well as the sense of ability to succeed (future planning, as defined by Carvalho et al., 2014).Although studies comparing these two constructs are scarce, these results corroborate those obtained by Bardagi and Hutz (2012) and Oliveira and Taveira (2016), suggesting that students who (im)migrate tend to feel more career-adjusted, consequently, less prone to poor performance and/ or circumvention if they understand their mobility for study within a professional life perspective.

Following the results, we observed that the structured style factor of resilience was the only predictor of the dimension study of the academic experiences. In other words, the use of learning resources offered by the university, time management and preparation for the tests (definition of the study dimension, according to Santos et al., 2005 ) can be predicted by the ability to manage time, objectives, timelines, rules and routines (structured style, by Carvalho et al., 2014).We can even observe some superposition between the definitions of the constructs, and the description of the study dimension seems to be the application of the structured style to the academic context.

Finally, the institutional dimension of academic experiences was significantly predicted by the social resources factor of resilience. This means that students who evaluate the institution attended in terms of teaching and infrastructure, wishing to remain in this university (aspects related to the institutional dimension of academic experiences, according to Santos et al., 2005) are those who receive help in difficult situations, which gives you a sense of belonging and sympathy from people who are outside the family context. 
This finding corroborates the findings of another study (Dupont et al., 2015), showing the role that the institution can play in facilitating the adaptation and institutional relationship with students, especially those coming from a different cultural context, such as in the case of the participants of this research.

Considering the difficulty to compose a robust sample, given the participants specificity, and the impact that a small sample can have in diminishing the statistical power of the analyzes carried (Wilson Van Voorhis \& Morgan, 2007), a special highlight must be made to the structured style predictor, since its relation to three criteria variables (personal and interpersonal dimensions and academic experiences study), lower the chances that the significant effects have been obtained randomly. In this sense, time management skills, organizing tasks and routines according to the achievement of pre-established goals and meeting deadlines and rules, seem to play an important role in overcoming stressors and vulnerability conditions that contribute to success in both their personal and relational aspects as well as in academic performance.

In addition to the discussions presented here, one can perceive a conceptual approximation between the structured style and the conscientiousness trait of the five great personality factors, since both are related to the ability and necessity, respectively, of organization, order and regulation (Carvalho, Souza, \& Primi, 2014; Carvalho et al., 2014).This relationship is relevant, since conscientiousness would be a predictor of well-being (Garcia, 2011) and academic performance (Poropat, 2009), and would be positively and significantly correlated with several aspects of social skills in university students (Bueno, Oliveira, \& Oliveira, 2001) .Moreover, the relationship between this trait and performance at work would be mediated by social skills (Witt \& Ferris, 2003). These relationships suggest that the conscientiousness trait can act as a facilitator of resilient behavior when the individual is in situations of greater stress and vulnerability.

\section{Final considerations}

This study sought to verify the association of cognitive variables (reasoning and executive functions) and resilient behaviors of (im)migrant university students with distinct aspects of adaptation to academic experiences. No associations were found between the variables of cognition and adaptation, possibly due to the use of self-report and performance measures in this study, which is the first limitation of this study.

Most of the factors that make up resilience, however, seem to be relevant to the adaptive process of these students. Among those, the major highlight was the structured style, having been predictor of three of the five dimensions of adaptation to academic experiences. A conceptual proximity between this factor and the conscientiousness trait of the five major factors is highlighted, which indicates that aspects of personality may influence the students' adaptation process. Therefore, the importance of future investigations in this subject that include the personality among the variables to be investigated is indicated.

In addition, both the number and heterogeneity (in terms of place of origin and language) of sample participants may have limited knowledge of more specific aspects of that population and decreased statistical significance of the analyzes. Therefore, it is suggested that new studies be carried out, with more representative samples and from different regions of Brazil, that could contribute to the knowledge of other aspects present in the adaptive process of these students.

Given the heterogeneity of languages, it was not possible to use versions of all the adapted and validated instruments for the various native languages of the participants. It is possible that such methodological limitation influenced the results found, and a greater delimitation of the characteristics of the sample is necessary to overcome this limit.

However, it is considered that, despite these limitations, this study offers relevant information for a better understanding of the adaptation of (im) migrant students. Such information can and should contribute to the development of university intervention programs and support to both students who migrate internally in Brazil and those who emigrate or immigrate. These programs constitute an important contribution that psychology can make to the academic community in order to favor a shorter adaptation process, increasing the chances that the personal and financial investments involved in this process will have the appropriate return.

\section{References}

Almeida, L. S., Nascimento, E., Lima, A. O. F., Vasconcelos, A. G., Akama, C. T., \& Santos, M. T. (2010). Bateria de Provas de Raciocínio (BPR-5): Estudo 
exploratório em alunos universitários. Avaliação Psicológica, 9(2), 155-162. Retrieved from: http:// pepsic.bvsalud.org/pdf/avp/v9n2/v9n2a02.pdf

Araújo, K. J. S., da Silva, A. M., da Silva Júnior, G. M. N., Carrijo, J. B., Caixeta, L. F., \& Bagasra, A. (2016). Sofrimento Mental: Avaliação Em Uma Universidade Americana. Revista Educação em Saúde, 4(2). Retrieved from: http://revistas.unievangelica. com.br/index.php/educacaoemsaude/article/ download/2018/1800

Bardagi, M. P., \& Hutz, C. S. (2012). Mercado de trabalho, desempenho acadêmico e o impacto sobre a satisfação universitária. Revista de Ciências Humanas, 46(1), 183-198. doi. org/10.5007/2178-4582.2012v46n1p183

Bermúdez, A. C. (2018, 26 de janeiro). Paraíba foi o Estado que mais recebeu estudantes de fora pelo Sisu em 2017. Uol. Retrieved from: https://educacao. uol.com.br/noticias/2018/01/26/paraiba-foi-oestado-que-mais-recebeu-estudantes-de-fora-pelosisu-em-2017.htm?cmpid= copiaecola

Blakemore, S. J., \& Bunge, S. A. (2012). At the nexus of neuroscience and education. Developmental cognitive neuroscience, 2, S1. doi: 10.1016/j.dcn.2012.01.001

Bolsoni-Silva, A. T., \& Loureiro, S. R. (2015). Anxiety and depression in Brazilian undergraduate students: the role of sociodemographic variables, undergraduate course characteristics and social skills. British Journal of Applied Science \& Technology, 5(3), 297-307. doi: 10.9734/ BJAST/2015/13004

Bueno, J. M. H., Oliveira, S. M. S. S., \& Oliveira, J. C. S. (2001). Um estudo correlacional entre habilidades sociais e traços de personalidade. PsicoUSF, 6(1), 31-38. doi: 10.1590/S1413-82712001000100005

Carvalho, L. D. F., Souza, B. D. B. D., \& Primi, R. (2014). Psychometric properties of the revised conscientiousness dimension of Inventário Dimensional Clínico da Personalidade (IDCP). Trends in Psychiatry and Psychotherapy, 36(1), 2331. doi: 10.1590/2237-6089-2013-0024

Carvalho, V. D., Teodoro, M. L. M., \& Borges, L. O. (2014). Escala de Resiliência para Adultos: aplicação entre servidores públicos. Avaliação Psicológica, 13(2), 287-295. Retrieved from: http:// pepsic.bvsalud.org/scielo.php?script=sci_arttext\&pid $=$ S1677-04712014000200016
Chan, R., Shum, D., Toulopoulou, T., \& Chen, E. (2008). Assessment of executive functions: review of instruments and identification of critical issues. Archives of Clinical Neuropsychology, 23, 201-216. doi: 10.1016/j.acn.2007.08.010

Cheng, H., \& Furnham, A. (2014). The associations between parental socio-economic conditions, childhood intelligence, adult personality traits, social status and mental well-being. Social indicators research, 117(2), 653-664. doi: 10.1007/ s11205-013-0364-1

Costa, A. C. F., \& Faria, L. M. S. (2014). Avaliação da inteligência emocional: a relação entre medidas de desempenho e de autorrelato. Psicologia: Teoria e Pesquisa, 30(3), 339-346. Retrieved from: https://repositorio-aberto.up.pt/ bitstream/10216/73911/2/92548.pdf

Diamond, A. (2013). Executive functions. Annual review of psychology, 64, 135-168. doi: 10.1146/ annurev-psych-113011-143750

DiTommasoa, E., Brannen-McNulty, C., Rossb, L., \&Burgessa, M. (2003). Attachment styles, social skills and loneliness in young adults. Personality and Individual Differences, 35, 303-312. doi: 10.1016/ S0191-8869(02)00190-3

Dupont, S., Galand, B., \& Nils, F. (2015). The impact of different sources of social support on academic performance: Intervening factors and mediated pathways in the case of master's thesis. Revue Européenne de Psychologie Appliquée/European Review of Applied Psychology, 65(5), 227-237. doi: 10.1016/j. erap.2015.08.003

Garcia, D. (2011). Two models of personality and well-being among adolescents, Personality and Individual Differences, 50(8), 1208-1212 doi: 10.1016/j. paid.2011.02.009

Greenberg, M. T. (2006). Promoting Resilience in Children and Youth. Annals of the New York Academy of Sciences, 1094, 139-150. doi: 10.1196/ annals.1376.013

Gremmen, M. C., Dijkstra, J. K., Steglich, C., \& Veenstra, R. (2017). First selection, then influence: Developmental differences in friendship dynamics regarding academic achievement. Developmental Psychology, 53(7), 1356-1370. doi:10.1037/ dev0000314 
Grech, L. B., Kiropoulos, L. A., Kirby, K. M., Butler, E., Paine, M., \& Hester, R. (2015). Coping Mediates and Moderates the Relationship Between Executive Functions and Psychological Adjustment in Multiple Sclerosis. Neuropsychology. doi: 10.1037/ neu0000256

Heaton, R. K., Chelune, G., Talley, J., Kay, G., \& Curtiss, G. (2005). Manual do Teste Wisconsin de Classificaşão de Cartas: Adaptação e padronižação brasileira. Revisão e ampliação. São Paulo: Casa do Psicólogo.

Hjemdal, O., Roazzi, A., Dias, M. G. B. B., Roazzi, M., \& Vikan, A. (2009). Exploring the psychometric properties of the resilience scale for adults in a Brazilian sample. In D. Elizur \& E. Yaniv (Eds.), Facet new horizons in theory construction and data analysis (pp. 120-138). Jerusalem: FTA.

Kobak, R. R. (1993). Attachment and the problem of coherence: implications for treating disturbed adolescents. Adolescent Psychiatry, 19, 137-149. Retrieved from: https://europepmc.org/abstract/ med/8296972

Lopes, R. M. F., Bastos, A. S., \& de Lima Argimon, I. I. (2017). Treino Das Funções Executivas em Idosos: Uma Revisão Sistemática da Literatura. Cuadernos de Neuropsicologia/Panamerican Journal of Neuropsychology, 11(1). Retrieved from: http://www.cnps.cl/ index.php/cnps/article/view/271

Luthar, S. S. (2015). Resilience in development: A synthesis of research across five decades. Developmental Psychopathology: Volume Three: Risk, Disorder, and Adaptation, 739-795. doi: 10.1002/9780470939406. ch20

Masten, A. S., Herbers, J. E., Desjardins, C. D., Cutuli, J. J., McCormick, C. M., Sapienza, J. K., ... \& Zelazo, P. D. (2012). Executive function skills and school success in young children experiencing homelessness. Educational Researcher, 41(9), 375-384. doi: 10.3102/0013189X12459883

Masten, A. S., \& Obradović, J. (2006). Competence and resilience in development. Annals of the New York Academy of Sciences, 1094(1), 13-27. doi: 10.1196/ annals.1376.003

Ministério da Educação (2018). Censo da Educação Superior: Notas Estatísticas 2017. Retrieved from: http://download.inep.gov.br/educacao_superior/ censo_superior/documentos/2018/censo_da_ educacao_superior_2017-notas_estatisticas2.pdf
Oliveira, I. M., \& Taveira, M. C. (2016). Desenvolvimento de carreira e processos acadêmicos: Uma articulação possível e necessária. Revista Brasileira de Orientação Profissional, 17(1), 12-18. Retrieved from: http://pepsic. bvsalud.org/scielo.php?script $=$ sci_arttext\&pi$\mathrm{d}=$ S1679-33902016000100003\&lng=pt\&tlng=pt

Ozben, S. (2013). Social skills, life satisfaction, and loneliness in Turkish university students. Social Behavior and Personality: an international journal, 41(2), 203-213. doi: 10.2224/sbp.2013.41.2.203

Perlin, A. P., Vestena, D., Damke, L. I., Patias, T. Z., \& Gomes, C. M. (2018). Percepção e satisfação de estudantes estrangeiros em uma instituição de ensino pública. Desenvolve Revista de Gestão do Unilasalle, 7(2), 37-51. doi: 10.18316/desenv.v7i2.4540

Polydoro, S. A. J., Primi, R., Serpa, M. N. F., Zaroni, M. M. H., \& Pombal, K. C. P. (2001). Desenvolvimento de uma escala de integração ao ensino superior. PsicoUSF, 6(1), 11-17. Retrieved from: http://pepsic.bvsalud.org/scielo.php?script=sci_arttext\&pid $=$ S1413-82712001000100003

Primi, R., \& Almeida, L. S. (2000). Estudo de Validação da Bateria de Provas de Raciocínio (BPR-5). Psicologia: Teoria e Pesquisa, 16(2), 165-173.doi: 10.1590/ S0102-37722000000200009

Primi, R., Santos, A. D., \& Vendramini, C. M. (2002). Habilidades básicas e desempenho acadêmico em universitários ingressantes. Estudos de Psicologia, 7(1), 47-55. Retrieved from: http:/ /www.scielo.br/ pdf/\%0D/epsic/v7n1/10953.pdf

Poropat, A. E. (2009). A meta-analysis of the five-factor model of personality and academic performance. Psychological bulletin, 135(2), 322-338. doi: 10.1037/ a0014996

Ribeiro, A., Calado, C., Cerveira, P., \& Oliveira, C. (2016). Personalidade e Funções Executivas nos estudantes do Ensino Superior. Interacções, 12(42), 125-136. Retrieved from: https://revistas.rcaap. $\mathrm{pt} /$ interaccoes/article/view/11817

Santos, A. A. A., Noronha, A. P. P., Amaro, C. B., \& Villar, J. (2005). Questionário de Vivência Acadêmica: Estudo da consistência internado instrumento no contexto brasileiro. In M. C. R. A. Joly, A. A. A. Santos, \& F. F. Sisto (Eds.). Questões do cotidiano universitário (pp. 159-177). São Paulo: Casa do Psicólogo. 
Schneider, W., \& Newman, D. (2015). Intelligence is multidimensional: Theoretical review and implications of specific cognitive abilities. Human Resource Management Review, 25(1), 12-27. doi: 10.1016/j. hrmr.2014.09.004

Soares, A. B., \& Del Prette, Z. A. P. D. (2015). Habilidades sociais e adaptação à universidade: Convergências e divergências dos construtos. Análise Psicológica, 33(2), 139-151. doi: 10.14417/ap.911

Soares, A. B., Seabra, A. M. R. D., \& Gomes, G. (2014). Inteligência, autoeficácia e habilidades sociais em estudantes universitários. Revista Brasileira de Orientação Profissional, 15(1), 85-94. Retrieved from: http:// pepsic.bvsalud.org/scielo.php? script $=$ sci_ arttext\&pid=S1679-33902014000100010

Silva-Filho, J. H. (2012). Manual da versão eletrônica Brasileira do teste Winsconsin de Classificação de Cartas. Manaus: UFAM.

Townsend, L., \& Scanlan, J. M. (2011). Self-efficacy related to student nurses in the clinical setting: a concept analysis. International Journal of Nursing Education Scholarship, 8(1). doi: 10.2202/1548-923X.2223

UNESCO Institute for Statistics (2014). Glossary. Retrieved from: http://glossary.uis.unesco.org/ glossary/en/term/2242/en.

Vries, M., \& Geurts, H. (2015). Influence of autism traits and executive functioning on quality of life in children with an autism spectrum disorder. Journal of autism and developmental disorders, 45(9), 27342743. doi: 10.1007/s10803-015-2438-1

Wigtil, C. J., \& Henriques, G. R. (2015). The Relationship Between Intelligence and Psychological Well-Being in Incoming College Students. Psychology of WellBeing, 5(1), 1-19. doi: 10.1186/s13612-015-0029-8

Witt, L. A., \& Ferris, G. R. (2003). Social Skill as Moderator of the Conscientiousness-Performance Relationship: Convergent Results Across Four Studies. Journal of Applied Psychology, 88(5), 809820. doi: 10.1037/0021-9010.88.5.809

Terry, D. R., Yue, Y., \& Lê, Q. (2014). Transition to an unfamiliar environment: International students> living experiences in an Australian regional area. Journal of the Australian and New Zealand Student Services Association (JANZSSA), (23), 10-20. Retrieved from: http://hdl.handle.net/11343/45186

Zhou, L., Lin, H., \& Lin, Y. C. (2015). Education, Intelligence, and Well-Being: Evidence from a Semiparametric Latent Variable Transformation Model for Multiple Outcomes of Mixed Types. Social Indicators Research, 125(3), 1011-1033. doi: 10.1007/s11205-015-0865-1

Recebido em: 11/03/2018 Reformulado em: 17/12/2018 
About the authors:

Emily Souza Gaião e Albuquerque - Psychologist. Master and PhD student in Psychology with emphasis in Cognitive Psychology at the Universidade Federal de Pernambuco and CNPq scholar. Professor at the Universidade Estadual da Paraíba (UEPB). Researcher at the Nucleus of Studies in psychological assessment (NEAP/UFPE).

ORCID: https://orcid.org/0000-0002-9117-6903

E-mail: emilygaiao@gmail.com

José Maurício Haas Bueno - Psychologist. PhD in Psychology by the Universidade São Francisco (USF). Professor of the Graduate Program in Cognitive Psychology at Universidade Federal de Pernambuco and Coordinator of the Nucleus of Studies in Psychological Evaluation (NEAP/UFPE). Universidade Federal de Pernambuco, Center of Philosophy and Human Sciences, Graduate Program in Cognitive Psychology.

ORCID: https://orcid.org/0000-0002-9179-7216

E-mail: mauricio.ufpe@gmail.com

\section{Contact:}

Universidade Estadual da Paraíba, Departamento de Psicologia, Rua Baraúnas, 351, Bairro Universitário Campina Grande-PB, Brasil

CEP: 58429-500 